\title{
Methodological principles of planning reorganization of the city of Naberezhnye Chelny during the development of the Master Plan-2022
}

\author{
Alexander Dembich ${ }^{1[0000-0001-8078-309 X]}$, Yulia Zakirova ${ }^{10000-0003-0143-2502]}$, Nataliia $^{\text {Orlova }}{ }^{1}{ }^{*}$ \\ [0000-0002-9194-7800], and Tansylu Khakimova ${ }^{1[0000-0002-4574-2126]}$
}

${ }^{1}$ Kazan State University of Architecture and Engineering, 420043, Zelenaya st., Kazan, Russia

\begin{abstract}
The purpose of the study is the definition of scientifically based principles of planning reorganization of the city of Naberezhnye Chelny. The main results of the study are the development of a program of urban development of the city territory on the basis of the identified problems and limitations, the definition of key tasks in the spatial and territorial development of the city of Naberezhnye Chelny. Significance of the results for architecture and urban planning consists in the fact that the methodological principles of the planning reorganization of the city as the basis for the development of the strategic master plan of the city of Naberezhnye Chelny are revealed.
\end{abstract}

Keywords: industrial monotown, planning reorganization, urban planning, master plan, Naberezhnye Chelny.

\section{Introduction}

The industrialization of the twentieth century gave a powerful impetus to the construction of industrial enterprises and factories, which required a large number of workers. During the Soviet period, this led to the creation of vast industrial areas and new cities. That is the reason why today in our country there is a large number of industrial cities. Change in general trends, decline in industrial production, growth of the service sector, change in the demand curve force these cities to change: there is a re-profiling of the economy, changes in the way of life of citizens. These changes require changes in the planning organization of the city. For example, the rigid functional zoning laid down in the cities of the twentieth century, at the stage of post-industrial development, becomes irrational, and a significant number of places of employment are built into residential areas. It is possible to distinguish the general trends of urban planning transformations that have occurred or should occur in industrial cities: mixed functional zoning, development of transport and communication framework, priority of public transport, strengthening of the green framework of the city, polycentricity of development, redevelopment of industrial facilities and territories, improvement of the quality of the urban environment. Naberezhnye Chelny is a large industrial city in the Republic of Tatarstan, and these urban-planning transformations are

* Corresponding author: natasha-131@mail.ru 
also relevant for it. However, it is necessary to take into account the peculiarities of the planning organization of the city, the specific landscape and geographical situation, as well as the specifics of the formation of the city in a short (and relatively recent) period of time. The planning structure of the city of Naberezhnye Chelny was formed as a result of the implementation of two urban planning concepts - the concept of a linear city and the concept of microdistrict (microrayon) development using an enlarged planning unit - intermain residential areas. It is also important to note that the city was not formed evolutionarily, but was built in a short time and for a specific economic task. The main cityforming enterprise in the city was the complex of plants «KamAZ», a manufacturer of heavy-duty vehicles.

Today, Naberezhnye Chelny is a territory of advanced development (TAD) and the center of the Kama River agglomeration. The functions of the city and the way of life are changing, the service sector is developing. However, in recent decades, the city has been characterized by haphazard, ill-conceived placement of service facilities, based on shortterm business opportunities and solutions, as well as the lack of a systematic urban planning policy of the often-replaced municipal leadership. Today, there is a need for a new urban planning policy that would address important issues of functional organization, and at the same time emphasize and strengthen the unique value of the city. There should be planning solutions that will form the basis of the Master plan of the municipal formation of the city of Naberezhnye Chelny.

The purpose of the study is to determine the methodological principles of planning reorganization of the city of Naberezhnye Chelny during the development and implementation of the Master Plan-2022, the key directions and content of territorial planning transformations, taking into account current and future socio-economic processes, strengths and weaknesses of the territory, global urban planning practices for the development of the cities of this type.

Initially, the decision to include the University in a complex and uncharacteristic practical urban planning work was based on the previous experience of the department, which has repeatedly developed more local design tasks for Kazan and the cities of Tatarstan. As well as systematic monitoring of urban development innovations in the field of regulatory and project activities both in Russia and in foreign practice.

The works of Lappo G. [1], Pertsik E. N. [2], Polyakova O. M. [3] and Gud I. D., Akhmedova E. A. [4, 5] studying the structure of urban agglomerations, their main structural elements, types of formation, features of territorial development, possible points of growth are considered in the field of agglomeration development. We have studied the works of Zubarevich N. V. [6], Akhmedova E. A. and Solodilov M. V. [7], Pilyasov A. N. and Zamyatina N. Yu. [8], devoted to the development of large industrial cities and the specifics of socio-economic and territorial development of single-industry towns.

The works aimed at studying the transformation of the planning structure of cities [9-11], and devoted to the development of the transport and communication framework on the scale of the city and agglomeration $[12,13]$ were considered. A significant number of studies are devoted to urban ecology $[14,15]$, the formation, identification, and strengthening of the «green framework» of industrial cities [16-18].

We also consider works that study various aspects of polycentric development at different scale levels (region, city, district) [19, 20]. Some studies also link polycentrism with the decentralization of production [21, 22]. The prospects for the development of industrial territories of large cities are considered in the works of researchers [23-25]. We have analyzed studies on the role of industrial regions in the city's economy at the stage of transition to postindustry, issues of revitalization, reconstruction of industrial areas [26, 27].

The issues of environmental transformations in cities [28, 29] and work on the identification of urban identity [30-32] are also considered. 


\section{Materials and methods}

The paper uses generally applicable scientific methods of research and solving problems of spatial planning, namely analysis of the chronology of urban development, identification of coordination between the socio-economic transformation of Russian society and the development and transformation of the urban environment.

The study is based on an integrated approach

1) analysis of literary sources and project practice, foreign and historical experience of the development of industrial cities with the prospect of transition to a new technological way of life;

2) study of the historical features of the formation and development of the city of Naberezhnye Chelny, analysis of chronological stages to identify the features and trends of the city's development;

3) analysis of urban planning and regulatory documentation made for the city of Naberezhnye Chelny, comparison of data from various sources;

4) complex field research, comparison of field research data. Also, a sociological study was conducted - a survey of city residents, conversations with experts, an analysis of «urban» social networks and local media publications.

The materials for this study are the current urban planning documentation of Naberezhnye Chelny and the adjacent Tukayevsky district, as well as previously developed (Master plans of previous stages of the city development), strategic planning documents of the Republic of Tatarstan, Naberezhnye Chelny, as well as the results of a full-scale study of Naberezhnye Chelny.

According to statistics for 2020, 533839 people live in the city, the dynamics of population changes is shown in the table 1 .

Table 1. The population of Naberezhnye Chelny.

\begin{tabular}{|c|c|c|c|c|c|}
\hline year & 2000 & 2005 & 2010 & 2015 & 2020 \\
\hline Population & 514700 & 507900 & 513193 & 524444 & 533839 \\
\hline
\end{tabular}

The initial data of the structural planning organization is as follows:

1) The city is divided into 3 administrative districts: Central, Avtozavodsky and Komsomolsky.

2) The generalized balance of the modern functional use of the city is presented in table 2 .

The balance sheet is drawn up for 2015 according to the current master plan of the city of Naberezhnye Chelny - 2017 (open data on https://fgistp.economy.gov.ru/).

Table 2. The balance of the use of the territory of Naberezhnye Chelny (as of 2015).

\begin{tabular}{|l|c|}
\hline \multicolumn{1}{|c|}{ Indicator } & $\%$ \\
\hline $\begin{array}{l}\text { Industrial, communal and storage territories and territories of } \\
\text { engineering structures }\end{array}$ & $22.7 \%$ \\
\hline Territories under surface water bodies & $12.5 \%$ \\
\hline Residential areas & $11 \%$ \\
\hline Territory of transport infrastructure & $10.5 \%$ \\
\hline Territories of collective gardens & $6.2 \%$ \\
\hline Public and business areas & $3.9 \%$ \\
\hline Recreational areas & $3.5 \%$ \\
\hline Territory of special purpose & $2 \%$ \\
\hline Other & $27.7 \%$ \\
\hline
\end{tabular}




\section{Results and Discussion}

Problems in the urban development of the city of Naberezhnye Chelny were identified in previously published author's studies (table 3).

Table 3. The problems of special development of the city of Naberezhnye Chelny.

\begin{tabular}{|l|l|}
\hline $\begin{array}{l}\text { The problems outlined by the 1972 } \\
\text { master plan of the city of Naberezhnye } \\
\text { Chelny }\end{array}$ & $\begin{array}{l}\text { Problems caused by changes in urban } \\
\text { planning policy in connection with the } \\
\text { emergence of the real estate market and new } \\
\text { trends in urban planning. }\end{array}$ \\
\hline $\begin{array}{l}\text { The lack of a rational polycentric } \\
\text { organization of the city's public center } \\
\text { system }\end{array}$ & $\begin{array}{l}\text { The problem of matching the mission and } \\
\text { status of the core of the Kama } \\
\text { agglomeration }\end{array}$ \\
\hline $\begin{array}{l}\text { The problem of the dominant transport- } \\
\text { oriented trend in the city's planning } \\
\text { structure }\end{array}$ & $\begin{array}{l}\text { The problem of the reorganization of the } \\
\text { main planning units of the residential zone } \\
\text { of the city - inter-main territories (enlarged } \\
\text { microdistricts) }\end{array}$ \\
\hline $\begin{array}{l}\text { The problem of the total uniformity of } \\
\text { the mass development of the residential } \\
\text { zone of the city. }\end{array}$ & $\begin{array}{l}\text { The problem of the connection of urban } \\
\text { public spaces with the Kama coast. }\end{array}$ \\
\hline
\end{tabular}

The priority tasks of development and transformation of the functional and planning structure and city environment are also highlighted:

- the role of the core of the Kama agglomeration

- identification of sites for new housing construction in undeveloped areas of the city, as well as on the territory of autonomous settlements and residential areas outside the city limits;

- development of agglomeration links, formation of a general agglomeration transport and communication framework, transformation of the city's transport infrastructure, taking into account transport projects at the macro level (agglomeration, regional scale);

- organization of the green framework of the city;

- transition to a polycentric urban structure, formation and development of a system of public centers of planning areas;

- formation of spatial connections-exits to the Kama River, mixed development of the coastal territory;

- development of the identity of the city, creation of an environmental design code for the city;

- emergence of a new system of «unique» objects that transform and strengthen the urban architectural brand.

The following strategic methodological principles of planning reorganization of Naberezhnye Chelny in the Master Plan-2022 are defined:

a) the urban agglomeration principle: «redundancy» of the development of the system of episodic service facilities and inclusion in the agglomeration communication and natural and recreational framework;

b) the principle of discrete self-sufficiency or the principle of differentiation by planning areas of the city;

c) the principle of forming «hybrid» microdistricts (the principle of reorganizing the local planning structure of existing microdistricts);

d) the principle of polycentricity of public centers and increasing connectivity in the planning structure of the public center of the city;

e) the principle of identifying and preserving the local identity of the urban environment; 
f) the principle of interconnectedness of planning development and the natural and recreational framework of the city:

1)The urban agglomeration principle: «redundancy» of the development of the system of episodic service facilities and inclusion in the agglomeration communication and natural and recreational framework is based on the «centrality» of the city's mission in the settlement system of the contiguous territory within a radius of up to $50 \mathrm{~km}$.

2) The principle of discrete self-sufficiency or the principle of differentiation by planning areas of the city assumes the preservation of the original principles laid down in the planning structure of the city. Naberezhnye Chelny has a microdistrict (microrayon) structure that was popular during the industrial period. However, according to the original idea in this case, the neighborhood had its own characteristics. Such a feature is the principle of discrete self-sufficiency. This principle is an attempt to use a two-stage service system, excluding the «everyday» combined with the periodic one. «New City» project designed by the team of B. Rubanenko, was in fact a «new planning area» of the city - an independent urban entity with its own planning center, adequate to the citywide (19th quarter), enlarged microdistricts (in area and population approaching the size of a residential area), and its own production area (an automobile plant complex). However, this principle was only partially implemented, mainly in terms of residential and transport infrastructure. The two-stage service system was implemented to a minor extent.

3) The principle of forming «hybrid» microdistricts (the principle of reorganizing the local planning structure of existing microdistricts) assumes the preservation of current microdistrict (microrayon) structure, that represents the period of the history of the Soviet Union. But at the same time, it is proposed to transform the microdistrict using the formation of an internal block grid. It helps to make microdistricts more convenient for modern usage, forming «hybrid» microdistricts that will combine the features of the block and microdistrict street and road grids gradually freeing up the ground floors of blocks of flats for new workplaces.

4) The principle of polycentricity of public centers and increasing connectivity in the planning structure of the public center of the city is provided by the development of transport and pedestrian network. The polycentric system of urban central places is formed from three sites:

- on the territory of the Azatlyk Square and the 19th microdistrict (the place reserved for the citywide center by the Master Plan of 1972);

- the center in the area of Mezhdurech'e, as a result of the redevelopment of the existing depressed industrial zone;

- an extensive linear center in the «old» city along Naberezhnye Chelny Avenue and the embankment of the Melekeska River;

- creation of a new community center in the potentially advanced planning area «Vostochny», combining the planned space-saving complexes of multi-apartment residential buildings and existing cottage settlements and rural settlements.

Transport networks and mobility are an essential and integral part of public space development strategies. It is proposed to create a system of urban public centers with increased connectivity of the road network and a system of pedestrian streets for comfortable movement. Since many microdistricts of the city of Naberezhnye Chelny have internal boulevards that were designed by the original master plan, the current project proposes to systematize this boulevard grid and combine it into one whole system. Thus, the entire boulevard network will have to connect public spaces with the Kama water area, local parks and squares on the city territory. The creation of an organized system of multilevel parking lots will help not only to make new territories for public urban spaces, but also to relieve microdistricts from car congestion, freeing up territories for boulevards and yard areas. 
5) The principle of identifying and preserving the local identity of the urban environment implicates using street-block development (as the most comfortable for a person to live in) in the historical part, its preservation and expansion to new territories. This principle takes into account the features and possibilities of the city of Naberezhnye Chelny, where a small historical part has been preserved and it is possible to preserve and develop the identity of the old city - «Mezhdurech'e» district. Another problem is to determine the identity of the city's development. For the rapid construction of residential and industrial facilities in Naberezhnye Chelny there were used standard panel structures. For this task, an industrial facility was created, which is the determinant that continues to produce its products at the present time. The problem of preserving the identity of an industrial city is not to destroy the economic and technological, construction base of the city, but to preserve it with a smooth transition to other technologies and a new economy. This will help to reduce greatly financial costs, as well as to preserve the historical foundation of the city. To achieve this smooth transition, the project proposes the efficient rehabilitation of buildings, creation of residential, administrative and other complexes with high energy efficiency, capable of generating and consuming energy from renewable sources in equal amounts on site during the entire period of operation, regardless of time of the year.

6) The principle of interconnectedness of planning development and the natural and recreational framework of the city.

Despite the fact that the city has a predominantly linear planning structure and stretches along the Kama coast, it has not received convenient and organic connections with the river coast. The spatial corridors left for these connections were partially built up. One of the most important urban planning tasks today is the active improvement of the coastal zone of the Kama River and small rivers (the Melekeska, the Chelny and the Shilna) that cross the city territory, and the implementation of continuous connectivity of coastal zones with landscape elements of internal green spaces. For the first time, planning decisions at the master plan level suggest using "green corridors» as the main boundaries between planning areas. These corridors assume the beginning from the coast of the Kama to the southeastern periphery of the city along the bed of small rivers and green strips along the meridional transport highways.

On the basis of these methodological principles, a «road map» of their implementation has been developed with recommendations on the timing of the implementation of these urban planning tasks.

\section{Conclusions}

Today, in the modern urban planning practice of Russia, the Master Plan in the execution that is prescribed in the current Urban Planning Code of the Russian Federation, becomes a very cumbersome tool of urban planning policy that is difficult to understand and difficult to implement as a tool of urban planning policy.

Working on the Master Plan of the city of Naberezhnye Chelny in contact with the local administration allowed us to identify the «pain points» of both the project document itself and the procedures for its use during implementation.

The problematic aspects of the urban development of Naberezhnye Chelny were specially identified for the municipal authorities as these issues should always be under the control of the city administration and the city community. Therefore, the system of project documents of the Master Plan includes a detailed «work flow chart» of the implementation of the principles of planning reorganization of the city and reveals their main essential characteristics. The work flow chart for effective control is also accompanied by a system 
for indicating its implementation, which allows you to «track» clearly and systematically the most important stages of the proposed Master Plan for the development of the territory.

\section{References}

1. G. M. Lappo, P. M. Polyan, T. V. Selivanova, Bulletin of the regional development Fund of Irkutsk region, 1, 45-52 (2007)

2. E. N. Pertsik, Academia. Architecture and Construction, 2, 63-69 (2009)

3. O. M. Polyakova, The regional agglomeration cultural environment integration and development with the use of the territory improvement information technology, IOP Conference Series: Materials Science and Engineering, 698 (2), 022009 (2019) DOI: 10.1088/1757-899X/698/2/022009

4. I. D. Gud, E. A. Akhmedova, Principles of urban planning development of suburban belt of Samara-Togliatti agglomeration, IOP Conference Series: Materials Science and Engineering. International Science and Technology Conference «FarEastCon 2019», 032060 (2020) DOI: 10.1088/1757-899X/753/3/032060

5. I. D. Gud, Multihub - point of increase in Samara agglomeration- conurbation spatial development, IOP Conference Series: Materials Science and Engineering 012018 (2020) DOI: $10.1088 / 1757-899 \mathrm{X} / 775 / 1 / 012018$

6. N. V. Zubarevich, Moscow University Bulletin. Series 5, Geography, 4, 38-44 (2017)

7. E. A., Akhmedova, M. V. Solodilov, Architecture and construction of Russia, 8 (212), 10-19 (2015)

8. A. Pilyasov, N. Zamyatina, Foresight and STI Governance, 10 (3), 53-64 (2016)

9. Yu. Arsenteva, E. Zaletova, S. Ismagilova, Structural transformation of small cities, IOP Conference series. Materials Science and Engineering 012011, Kazan, Russia (2020) DOI: 10.1088/1757-899X/890/1/012011

10. E. A. Zaletova, Izvestija KGASU, 3 (45), 105-113 (2018)

11. J. Kubeš, Z. Kovács, Urban Studies, 57 (13), 2591-2611 (2020) DOI: $10.1177 / 0042098019889257$

12. V. R. Vuchic, Transportation for livable cities, Routledge, 376 (2017) DOI: $10.4324 / 9781351318167$

13. M. Blinkin, Russia: Strategy, Policy and Administration, 195-204, (2017) DOI: 10.1057/978-1-137-56671-3_18

14. L.M. Musina, M.U. Neucheva, Role of the state in solving the environmental problems of the industrial monoprofile cities, IOP Conference Series: Earth and Environmental Science, 107 (1), 012132 (2018) DOI: 10.1088/1755-1315/107/1/012132

15. A. Lyapin, I. Druzhinina, Greenways as a new type of urban green construction at the foreign architectural practice, IOP Conference Series: Materials Science and Engineering, 667 (1), 012059 (2019) DOI: 10.1088/1757-899X/667/1/012059

16. I. Prydko, Green Architecture as a Means of Sustainable Urban Development: Russian and International Experience, MATEC Web of Conferences, 193, 9 (2018) DOI: 10.1051 / matecconf / 201819304015

17.Z. Tan, KKL Lau, A. C. Roberts, S. T. Y. Chao, E. Ng, International Journal of Environmental Research and Public Health, 16 (22), 4423 (2019) DOI: $10.3390 /$ ijerph 16224423

18. S. Kh., Ismagilova, Izvestija KGASU, 4 (42), 129-135 (2017)

19. M-J. Jun, Cities, 98, 102587 (2020) DOI: 10.1016 / j.cities.2019.102587

20. W. Zhang, B. Derudder, Urban Studies, 56 (16), 3339-3357 (2019) DOI: 10.1177 / 0042098019843061

21. Y. Li, Computers, Environment and Urban Systems, 80, 101425 (2020) DOI: 10.1016/j.compenvurbsys.2019.101425 
22. T. Sun, Y. Lv, Cities, 99, 102617 (2020) DOI: 10.1016/j.cities.2020.102617

23. T. V. Mirolubova, R. S. Nikolaev, Ars Administrandi (The art of management), 10 (4), 569-597 (2018) DOI: 10.17072/2218-9173-2018-4-569-597

24. I. Vershinina, A. Kurbanov, A. Liadova, Ecology and Industry of Russia, 22 (8), 65-71 (2018) DOI:10.18412/1816-0395-2018-8-65-71

25. V. Filatov, Zh. Dibrova, N. Zhukova, Renovation of industrial territories in single industry towns on the basis of industrial parks, MATEC Web of Conferences, 170, 110 (2018) DOI: 10.1051/matecconf/201817001131

26. A. Eglins-Eglitis, I. Lusena-Ezera, Procedia Economics and Finance, 39, 122-130 (2016) DOI: 0.1016/S2212-5671(16)30256-8

27. A. Mahzouni, Journal of Cleaner Production, 195, 1476-1486 (2018) DOI: 10.1016/j.jclepro.2017.11.116

28. E. A. Zalyotova, Izvestija KGASU, 3 (41), 67-74 (2017)

29. O. M. Polyakova, Architecture-design support implementation of the strategy socioeconomic development the urban district, IOP Conference Series: Materials Science and Engineering 698 (3), 033012 (2019) DOI: 10.1088/1757-899X/698/3/033012

30. A. Stepanchuk, S. Gafurova, M. Latypova, "Genius loci» as a resource for the development of historical areas of the city, IOP Conference series. Materials Science and Engineering 012013, Kazan, Russia (2020) DOI: 10.1088/1757899X/890/1/012013

31. E. Goran, Cities, 99, 45-51 (2020) DOI: 10.1016/j.cities.2020.102648

32. Y. A. Efremova, O. N. Goryacheva, R. F. Kurbanova, Journal of Environmental Treatment Techniques, 7, 925-929 (2019) 